\title{
THE IMPACT OF MANAgerial Discretion ON FIRM PERFormanCE
}

\author{
Anisya Susan Thomas \\ Florida International University \\ Miami, Florida \\ Joseph Peyrefitte \\ Florida Atlantic University \\ Ft. Lauderdale, Florida
}

\begin{abstract}
Theoretical arguments from two distinct literatures are integrated to develop a model which attempts to shed further light on the determinants of performance in multinational corporations. It is suggested that the ambiguity of results in prior investigations could be attributed to variations in managerial discretion. Building on the concept of managerial discretion, it is hypothesized that in high discretion settings, organizational and leadership factors will be associated with performance. In contrast, in low discretion settings, where environmental factors predominate, managers have limited latitude; therefore, the impact of these factors on performance will be limited. These hypotheses are tested in two different industry settings. The results largely confirm the theoretical contentions.
\end{abstract}

\section{Introduction}

The theoretical roots of international business (IB) are reflected in a rapidly evolving discipline where alternative perspectives and paradigms are continuously introduced and evaluated. While the multiplicity of different approaches contributes to the richness of the field, the failure to synthesize theories has also led to barriers between scholars and the duplication of research across distinct functional areas. In commenting on this trend, Dunning (1989) suggests that the advancement of academic excellence in IB will be best achieved by integrating relevant parts of multiple disciplines. In other words, interdisciplinary research which transcends functional borders to develop explanations for the success and failure of organizations in the global arena will contribute substantially to an enhanced understanding of the complexities of a multidimensional field.

In this paper we build upon studies in international business and strategic management to explore the determinants of success in multinational corporations (MNCs). By using the concept of managerial discretion, we integrate these theo- 
retical platforms and develop an argument for the differential impact of environmental, organizational, and leadership factors on financial outcomes. Our model is then empirically tested and directions for future research are delineated.

\section{Hypotheses}

The determinants of performance in large MNCs are an area of persistent and enduring interest to researchers in the field of international business. During the last two decades, several studies have explored the impact of various factors on the success and growth of these organizations (e.g., Daniels \& Bracker, 1989; Geringer, Beamish, \& daCosta, 1989; Grant, 1987; Haar, 1989; Rugman, 1983; Sullivan, 1994b). The variables hypothesized to affect MNC performance include organizational factors such as the level of international involvement (multinationality), firm nationality, product diversification, direction of international involvement, advertising expenditures, and research and development spending in addition to environmental factors such as industry differences. Although there have been a wealth of studies, empirical findings from these efforts provide little consensus regarding the impact of various internal and external forces on performance outcomes. For example, Daniels and Bracker (1989), Dunning (1981), Haar (1989), and Kumar (1984) failed to find a link between multinationality and MNC profitability or growth. In contrast, Grant (1987), Kim, Hwang, and Burgers (1989), and Mitchell, Shaver, and Yeung (1993) found positive associations, while Siddharthan and Lall (1982) found negative relationships between the same variables. Complicating the matter even further, Geringer, et al. (1989) and Sullivan (1994b) found curvilinear relationships between the degree of internationalization and performance. Similar contradictions characterize the study of the impact of other organizational factors such as $R \& D$ spending and capital intensity on the performance of multinational enterprises (e.g. Severn \& Laurence, 1974; Siddharthan \& Lall, 1982; Vernon, 1971). In addition, industry differences have been shown to have both significant (Daniels \& Bracker, 1989; Haar, 1989) and insignificant (Grant, 1987) effects on profitability. Table 1 provides a review of the empirical findings in selected studies of MNC performance (for extensive methodological reviews, see Ramaswamy (1992) and Sullivan (1994a)).

In spite of two-and-a-half decades of research of the phenomenon, there does not seem to be any consistent pattern in the relationships between various internal and external factors and the performance of MNC's. However, there is a movement away from the examination of individual, unidimensional indicators to more multidimensional conceptualizations that incorporate the combined impact of the organization and environment, through the consideration of constructs such as the role of strategy (Geringer et al., 1989). Despite the dominance of the rational-economic and market power models in the literature (see Table 1), and the lack of empirical evidence, there is also consid erable agreement that the leaders of multinational organizations do in fact play 
Table 1

Review of Empirical Findings in Studies of MNC Performance ${ }^{a}$

\begin{tabular}{lll}
\hline Study & Sample & Findings \\
\hline Vernon (1971) & 187 Fortune 500 firms & MNCs earned higher returns than non- \\
& & MNCs. Advertising intensity and R\&D \\
& intensity were also associated with higher \\
& returns; MNCs typically reflect higher \\
levels of advertising and R\&D intensity.
\end{tabular}

Severn \&

Laurence

(1974)

Buckley,

Dunning,

Pearce (1978)

Dunning (1981) 188 large U.K MNCs in 1979

Siddharthan \& 74 largest U.S.MNCs Lall (1982) in 1976-79

Rugman (1983) 50 largest U.S.MNCs, 50 largest European MNCs

Kumar (1984) 672 U.K. quoted cos., $1972-76$

Michel \& 58 MNCs, 43 non-

Shaked (1986) MNCs (U.S.)

Grant (1987) 304 British MNCs

Grant, $\quad 304$ British MNCs

Jammine, \&

Thomas (1988)
No association between foreign direct investment and profitability. Overseas profitability was associated with level of R\&D.

Level of overseas activity had a positive relationship with organizational growth for one period of the study.

Overseas production was insignificantly related to return on assets.

Overseas ratio had a negative influence on firm growth once firm size, advertising, R\&D intensity, scale economies, and profitability were taken into account.

European MNCs were less profitable than U.S. MNCs. Size and risk were not significant.

MNCs earned higher return on assets and on sales than domestic firms. Overseas ratio was not significantly related to profitability and growth.

Risk-adjusted performance is superior for non-MNCs.

Multinationality was positively associated with superior profitability. Destination of overseas expansion and industry effects were not significant.

Product diversity led to declining profitability once firms encountered limits to complexity. However, multinational diversity was strongly related to profitability. 
Table 1

Review of Empirical Findings in Studies of MNC Performance a cont'd

\begin{tabular}{|c|c|c|}
\hline Study & Sample & Findings \\
\hline $\begin{array}{l}\text { Daniels \& } \\
\text { Bracker (1989) }\end{array}$ & 116 large U.S. firms & $\begin{array}{l}\text { The relationship between profit perfor- } \\
\text { mance and dependence on foreign opera- } \\
\text { tions varied widely according to industry }\end{array}$ \\
\hline $\begin{array}{l}\text { Geringer, } \\
\text { Beamish, \& } \\
\text { DaCosta (1989) }\end{array}$ & $\begin{array}{l}100 \text { largest U.S. MNCs, } \\
100 \text { largest European } \\
\text { MNCs }\end{array}$ & $\begin{array}{l}\text { U.S. MNCs were more profitable than } \\
\text { European MNCs. Related diversification } \\
\text { strategies yielded superior performance. } \\
\text { The degree of internationalization } \\
\text { exhibited a positive relationship with } \\
\text { performance until a threshold level was } \\
\text { reached. }\end{array}$ \\
\hline
\end{tabular}

Haar (1989) 50 largest U.S. MNCs, Past performance, industry, and 50 largest European nationality significantly impacted MNCs, 50 largest Japanese MNCs

Kim, Hwang, 62 U.S. MNCs Burgers (1989) performance. Size, state ownership, and multinationality were not significant.

Profitability varied with the extent of internationalization. Related diversifiers outperformed unrelated diversifiers. However, unrelated diversifiers that were well diversified internationally outperformed those that were not.

\begin{tabular}{|c|c|}
\hline Mitchell, & $\begin{array}{l}17 \text { U.S. firms in a } \\
\text { "domestic" industry }\end{array}$ \\
\hline Yeung (1993) & $\begin{array}{l}18 \text { U.S. firms in a } \\
\text { "transition" industry }\end{array}$ \\
\hline Blaine (1994) & $\begin{array}{l}100 \text { large industrial } \\
\text { companies each in } \\
\text { Germany, Japan, and } \\
\text { the U.S. }\end{array}$ \\
\hline
\end{tabular}

International expansion returns superior performance in both domestic and transition industries.

Only minor differences were found in the financial performance of large multinational firms (each derives a substantial portion of its revenues from foreign operations) from three nations. Accounting differences across countries were controlled for; thus these factors did not play a significant role in the minor differences across firms. 
Table 1

Review of Empirical Findings in Studies of MNC Performance cont'd

\begin{tabular}{|c|c|c|}
\hline Study & Sample & Findings \\
\hline $\begin{array}{l}\text { Carpano, } \\
\text { Chrisman, \& } \\
\text { Roth (1994) }\end{array}$ & $\begin{array}{l}319 \text { U.S. MNCs from } \\
33 \text { industries }\end{array}$ & $\begin{array}{l}\text { Geographic scope and segment } \\
\text { differentiation were used to distinguish } \\
\text { four international strategies in global and } \\
\text { multidomestic industries (segmented, } \\
\text { mass-market, segmented-focus, and } \\
\text { focus). Performance across the strategies } \\
\text { varied with the measure of performance } \\
\text { (ROI or sales growth). However, } \\
\text { conclusive results were found in global } \\
\text { industries. In global industries } \\
\text { segmented and focus strategies were } \\
\text { more effective than segmented-focus } \\
\text { strategies. }\end{array}$ \\
\hline $\begin{array}{l}\text { Sullivan } \\
\text { (1994b) }\end{array}$ & $\begin{array}{l}100 \text { largest U.S. MNCs, } \\
100 \text { largest European } \\
\text { MNCs; } 75 \text { most } \\
\text { international U.S. } \\
\text { manufacturing MNCs }\end{array}$ & $\begin{array}{l}\text { Using the foreign sales/total sales ratio, } \\
\text { the threshold of internalization (Geringer, } \\
\text { Beamish \& DaCosta[1989]) was } \\
\text { confirmed; however, when } \\
\text { internationalization was measured with } \\
\text { an "international scale," the threshold } \\
\text { was not confirmed; MNCs of slight } \\
\text { and high degrees of internationalization } \\
\text { experienced both low and high degrees } \\
\text { of profitability. }\end{array}$ \\
\hline
\end{tabular}

a For extensive methodological reviews see Ramaswamy (1992) and Sullivan (1994a).

an important role in designing responses to environmental challenges and marshalling organizational resources to meet them. Thus, the extant knowledge about the predictors of performance in multinational organizations can be restated in an integrated form as:

\section{H1: The performance of MNCs is a function of environmental, orga- nizational, and leadership factors.}

However, investigations of MNC performance continue to emphasize methodological solutions to explain the ambiguity and contradictions that characterize the literature (see Sullivan, 1994a). While new methodological approaches are critical to the advancement of knowledge, we contend that in order to move towards a better understanding of MNC performance, there is a need for a broader, more holistic conceptualization which looks beyond the findings of any individual study. Instead, the focus should shift to the 
search for theoretical explanations of why factors such as the extent of involvement in foreign activities contributes to performance in some situations but not in others. We suggest that a potential reason for the differential impact of environmental and organizational factors on the performance of MNCs is managerial discretion, an emerging concept in the field of strategic management.

\section{Managerial Discretion: The Missing Link?}

The relative importance of managers and the environment to the success and failure of organizations is a source of considerable debate in the strategic management and organization theory literatures. Advocates of the strategic choice paradigm (Child, 1972) suggest that managers are the main arbiters of organization direction and performance. They suggest that since managers choose the domain for the firm's activities, decide on its resource allocation priorities, and design competitive maneuvers, they are directly responsible for its success or failure.

In contrast, the proponents of the population ecology perspective contend that the success or failure of organizations is determined by inertial and environmental forces. In their view, organizational survival is largely dependent on environmental selection (Hannan \& Freeman, 1977; Aldrich, 1979). Thus, in the framework of this theory, the role of managers and strategy becomes less important to organization performance.

These opposing theoretical perspectives have each received considerable empirical support (e.g. Lieberson \& O'Connor, 1972; Gupta \& Govindarajan, 1984). However, their incompatibility has often resulted in mutually exclusive, yet parallel research. In other words, researchers subscribing to these alternative theoretical perspectives often investigate the same phenomena using different lenses. The mixed results of these efforts have highlighted the necessity of bringing these world views closer together. Theorists in both camps (Hannan \& Freeman, 1977; Miles \& Snow, 1978; Tushman \& Romanelli, 1985) seem to agree that each perspective may be more useful in some circumstances than in others.

In addressing this issue Hambrick and Finkelstein (1987) developed the concept of managerial discretion. Managerial discretion refers to the latitude of managerial action. More specifically, it pertains to the ability of a Chief Executive Officer (CEO) to exert his or her influence in a variety of substantive and symbolic domains such as resource allocation, product-market selection, or the launching of competitive initiatives. Hambrick and Finkelstein (1987) argue that different CEOs have different ranges of decision making options available to them, determined by a combination of environmental, organizational and personal factors. In other words, although environmental, organizational and leadership factors all have the potential to influence outcomes, the relative importance of each can vary by situational constraints.

Hambrick and Finkelstein (1987) illustrate the impact of environmental factors on the level of managerial discretion in their argument which compares 
the latitude available to the CEO of a public utility and his or her counterpart at a medium-sized microcomputer firm.

"The computer executive has legitimate options in the areas of pricing, promotion, production technology and locations, distribution, joint ventures and sales force incentives (to name but a few); and, realistically speaking, the utility executive's options in these areas are limited or even nil. Viewed another way, the two executives may be said to have the same possible domains of action, but greatly different ranges of discretion in many of those domains" (1987:372).

In the former instance, the top manager could make and execute decisions that change the direction and focus of the organization. For example, the decision of Steve Jobs to maintain the closed architecture in the machines produced by Apple Computer Corp. set the company on an entirely different course from its competitors in the industry. However, in the latter case of the utility executive, the restrictive web of regulatory constraints imposed by environmental and governmental forces largely reduces the leadership role to that of a figurehead. In other words, identical decisions made by the CEOs of the computer and utility firms will affect each organization in a different way. Theoretically, because of the greater latitude available to the computer executive, the decision will have a much more immediate and significant impact on organizational performance. In contrast, the impact of the utility executive will be substantially diluted by the dominance of external environmental factors such as government regulation and environmental legislation. Thus in some environments, managerial actions can alter the course of organizations. In others, environmentally determined factors predominate, limiting executive influence.

This theory can be extended to the domain of MNC performance. It is reasonable to theorize that in high discretion settings where managers have the flexibility to make and execute strategic choices about whether to invest in new technologies or enter new markets, a relationship between leadership factors, such as the profile of top managers and strategic factors such as the level of R\&D spending and performance outcomes can be expected. Since managerial discretion encompasses choices that may be beneficial or detrimental, the relationship may be positive or negative. Conversely, in low discretion settings characterized by powerful competitors, suppliers or buyers, low or negative growth rates and long-term contractual obligations, firms may be subject to strong inertial or market forces which overshadow or negate these linkages. Thus we hypothesize that:

H2: The relationship between organizational and leadership factors and MNC performance will vary with the constraints on managerial discretion. Organizational and leadership factors have a greater impact on performance in high discretion settings in comparison to low discretion settings. 


\section{Operationalizing Managerial Discretion}

Although Hambrick and Finkelstein (1987) defined managerial discretion to be comprised of three sets of forces, the environment, the organization and the chief executive, most studies have operationalized this concept in terms of the environmental component, using industry as a surrogate for the environment. To quote Finkelstein and Hambrick (1990):

"Organizations function within domains defined by their products or services and by the markets they serve (Levine and White, 1961). The characteristics of these domains, particularly the industry the firm competes in, greatly affect the level of managerial discretion. For example, Lieberson and O'Connor (1972) found that more variance in profitability could be attributed to CEOs in industries with high advertising intensity and high growth rates - both of which signal discretion (Hambrick and Finkelstein, 1987) - than in more commodity like or low growth industries... Industries may differ along several important dimensions that affect the level of managerial discretion. One such dimension is product differentiability. Industries characterized by product differentiability offer managers discretionary domains that are not available in commodity goods industries.... Other sources of environmental discretion are demand instability, low capital intensity, competitive market structures, market growth and freedom from government regulation. Industries that are characterized by these factors offer greater discretion to top managers than do other industries (489)."

The logic that the extent of discretion available to top managers varies by industry setting has been implicitly acknowledged in several studies of MNC performance. For example, Daniels and Bracker (1989) noted that the positive association between multinationality and profit varied widely by the industry environment. They revealed that in industries subject to heavy government regulation (such as aerospace), the multinationality-performance link was very weak. On the other hand, in the differentiated drugs and pharmaceutical industry, this association was much stronger. Significant industry differences were also substantiated by Haar (1989) and Carpano, Chrisman, and Roth (1994). Therefore in this study, managerial discretion is assessed by industry membership.

\section{Operationalizing Strategic Leadership}

The study of top managers, a field now referred to as strategic leadership, has become a central area of inquiry in strategic management. The origins of this research stream are usually attributed to Hambrick and Mason (1984) who built on the work of the behavioral theorists (Cyert and March, 1963; March and Simon, 1958) to explain the link between executive characteristics and organi- 
zational outcomes. In their view (a) managers have a limited field of visionthey can only scan some aspects of the organization and its environment, (b) managers selectively perceive only bits of information in their fields of vision (c) the information is then interpreted through a filter formed by the manager's cognitive base and values (d) this individualistic interpretation is the basis of strategic choices. Thus, choices made by managers on behalf of the organization reflect the characteristics of these managers, underlining the important role that managers play in determining organizational performance.

The literature in strategic leadership suggests that since the cognitive bases which influence information gathering and evaluation are a product of backgrounds, experiences and training, demographic characteristics, such as age and education, can be used to assess this construct (Wiersema \& Bantel, 1992). The efficacy of the demographic approach has been demonstrated in numerous investigations of the relationship between managerial characteristics and organizational outcomes (e.g. Chaganti \& Sambharya, 1987; Gupta \& Govindarajan, 1984; Thomas, Litschert \& Ramaswamy, 1991; Wiersema \& Bantel, 1992). For example, Wiersema and Bantel (1992) found that attributes such as top management team youth, organizational tenure, educational level, and functional backgrounds were useful indicators of an organization's propensity for strategic change. Thus, in keeping with the tradition of research in strategic leadership, the impact of managers on performance is examined by considering the relationship between the demographic profiles of the CEOs and financial performance.

\section{Method}

\section{Sample and Setting}

Our sample was restricted to U.S. based multinationals in order to control for variations in national context which inevitably influence the competitive posture and behavior of firms (Porter, 1990). The initial sample consisted of all the firms in the electronics and computer industries (SIC 367 and 368) and the chemical and petroleum industries (SIC 281 and 291) listed in Fortune magazine's 500 largest industrial organizations that (a) had international sales and (b) for which top manager data were available. These industries were specifically chosen as prior research (see for example, Finkelstein and Hambrick, 1990; Hambrick and Finkelstein, 1987) found that they represented distinct levels of managerial discretion.

Since comparative analysis indicated a large overlap in products and a lack of significant differences in terms of growth rates, size and profitability, the firms in the electronics and computer industries were combined to represent the high discretion setting and the firms in the chemical and petroleum industries were combined to represent the low discretion setting. The high discretion sample consisted of 28 firms that exhibited a high degree of product differentiability, low capital intensity and rapid growth (84\% over five years), 
characteristics specified by Hambrick and Finkelstein (1987) as being typical of settings where managers had greater latitude. The low discretion sample consisted of 32 firms that together typified an industry that was mature, had lower growth rates (5\% over five years), established patterns of investment and subject to considerable government regulation, all characteristics of contexts where managerial latitude is constrained. Table 2 presents the descriptive statistics for all the variables in the study.

\section{Measures and Data}

Environmental Factors. As discussed above, industry was used to operationalize the degree of discretion in firms' task environments. Dummy variables were used to code firms in either high or low discretion environments. The electronics and computer industry represented the high discretion setting and the chemicals and petroleum refining industry represented the low discretion setting.

Organizational Factors. Organizational factors were defined in terms of variables that have been found to affect the performance of MNCs in previous studies. Data on organizational factors were collected for five years (19831987) from the 1989 Directory of Multinationals, the Fortune 500 annual issues and COMPUSTAT II tapes. Three distinct measures were used to operationalize this construct. These are detailed below:

Multinationality, an indicator of the level of a firm's involvement in overseas activity, was measured as the proportion of overseas sales to total sales, in keeping with the measurement scheme utilized by prior research (e.g. Daniels and Bracker, 1989; Grant, 1987; Haar, 1989).

$R \& D$ intensity, an indicator of a firm's propensity to differentiate itself, was measured as the ratio of R\&D expenses/total sales (e.g. Kumar, 1984; Siddharthan \& Lall, 1982).

Capital intensity, a common indicator of a firm's strategic focus on efficiency and low cost, was measured as the ratio of capital expenses per dollar of total sales.

Leadership Factors. A large body of literature suggests that the Chief Executive Officer (CEO) in a corporation provides the primary direction of strategic decision making by leading the firm's emergent social systems or dominant coalitions (e.g. Lorange, 1980; Pearce \& Robinson, 1987). Further Hambrick and Finkelstein's (1987) theory of managerial discretion was explicitly related to the latitude of the CEO. Hence the CEO was the unit used to measure the leadership construct. Data on the chief executive officers were obtained from BusinessWeek and Dun and Bradstreet's Reference Book of Corporate Managements. 
Table 2

Means, Standard Deviations, and Correlations for all Variables ${ }^{a, b}$

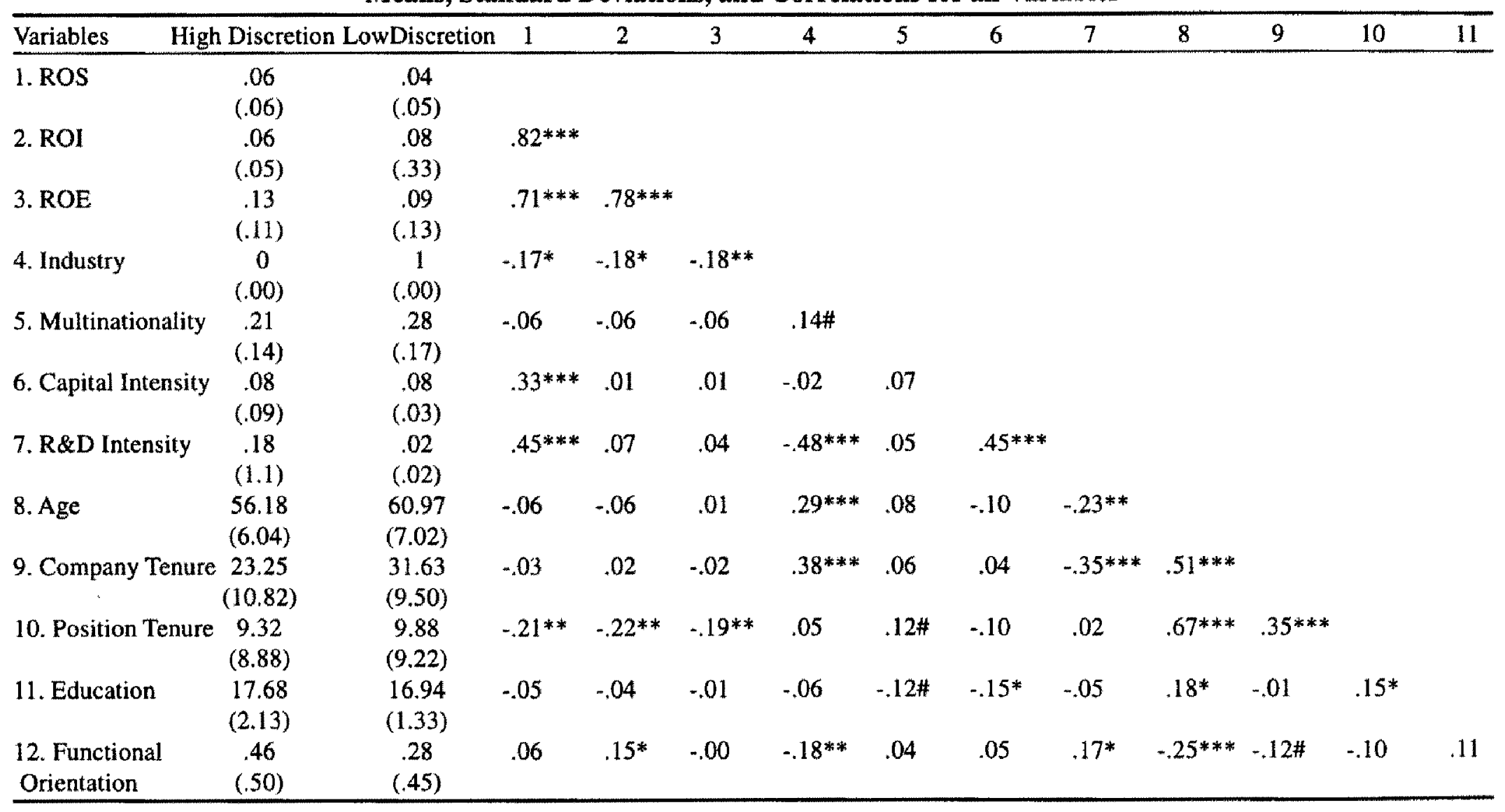

${ }^{2}$ Standard deviations appear in parentheses $\quad \# p<.10 \quad{ }^{*} p<.05 \quad{ }^{* *} p<.01 \quad{ }^{* * *} p<.001$

"Means and standard deviations are based on 5 year averages 
Five demographic dimensions, previously found to be related to organizational outcomes, were used to operationalize this construct. These were:

Age. The age of the CEO has been linked to the manner in which a decision is reached and decision quality (Kirchner, 1958). Studies have consistently found that younger managers are associated with growth, innovation and risk taking, while older managers are more risk averse and tend to make more conservative decisions (Carlsson \& Karlsson, 1970; Stevens, Beyer \& Trice, 1978). In this study, age was measured as the chronological age of the CEO.

Tenure in the Company and Position Tenure (both in the company and in the position) has been used as a proxy for experience in the organization (Kotter, 1982). Previous research indicates that organizations pursuing efficiency strategies tend to be led by longer tenured executives who have been promoted from within the organizations, while market seeking organizations have a greater propensity to recruit from the outside (Miles \& Snow, 1978; Thomas et al., 1991). Two separate indicators were used to assess managerial tenure, the number of years spent in the company and the number of years in the position of CEO.

Education The amount of formal education possessed by the leader has been found to be associated with organizational innovation (Kimberly and Evanisko, 1981). Better educated executives are more receptive to new ideas. Thus, the level of education possessed by the CEO was used as another indicator of the managerial characteristics construct. To operationalize this measure, a coding scheme was devised whereby each year of college education was added to a base score of 12 (for example, bachelor's degree $=12+4=16$, master's degree $=12+6=18$, etc.).

Functional Orientation has been related to the way in which executives approach and solve problems. For example, Dearborn and Simon (1958) found that when a group of executives from different functional backgrounds were presented with the same problem, they tended to define it primarily in terms of the activities of their own function. Hambrick and Mason (1984) built on this logic to classify various functional specializations as either "output" functions or "throughput" functions. Output functions emphasize externally oriented activities such as developing products to meet market trends and searching for new domain opportunities, while throughput functions focus on the efficient transformation of inputs to outputs. Following this logic, Functional orientation was dummy coded as either output oriented (e.g. R\&D, marketing) or throughput oriented (e.g. finance, production and manufacturing). 
Performance. Performance was measured using three separate financial ratios, return on sales (ROS), return on investment (ROI), and return on equity $(R O E)$. Performance data were collected from COMPUSTAT II tapes and cross-validated with the annual survey.

\section{Data Analysis}

The data analysis was conducted using pooled Ordinary Least Squares (OLS) regressions. The cross-sectional organizational data were pooled in order to detect the average effect of the independent variables over the five year period (1983-1987). Although pooling the data could violate some of the assumptions underlying OLS regression, the approach is defensible because tests of autocorrelation (Durbin Watson's D) suggested that the errors were uncorrelated. To test Hypothesis 1, each performance measure was regressed on environmental, organizational, and leadership factors. The results of this analysis are presented in Table 3.

To test Hypotheses 2, six separate regression models were developed to assess the impact of organization and leadership factors on each performance measure under high and low discretion environments. The number of observations in the regressions varied between 140 and 160 . The results of these analyses are presented in Table 4. During our initial analysis we also separately regressed the performance variables on the organizational factors alone and also the leadership factors alone, yielding twelve separate regressions. However, these analyses provided only five significant $F$ statistics, suggesting that performance cannot be explained by either organizational or leadership factors alone.

\section{Results and Discussion}

Hypothesis 1 essentially reflected the findings of prior research and formed the baseline for the test of managerial discretion in multinational organizations. According to this hypothesis: The performance of MNCs is a function of environmental, organizational, and leadership factors. This hypothesis was clearly supported. As indicated in Table 3, the combination of environmental, organizational and leadership factors consistently explained a significant proportion of variance in each performance indicator. Although the proportion of variance explained ranges from $35.3 \%$ (ROS) to $15.4 \%$ (ROI) and $13.7 \%$ (ROE), in each case the equations are statistically significant. 
Table 3

Pooled OLS Regression Analyses"

\begin{tabular}{|c|c|c|c|}
\hline Variables & ROS & ROI & ROE \\
\hline Intercept & $\begin{array}{l}-.125^{*} \\
(.05)\end{array}$ & $\begin{array}{l}-.034 \\
(.056)\end{array}$ & $\begin{array}{l}-.175 \\
(.133)\end{array}$ \\
\hline Industry & $\begin{array}{l}-.004 \\
(.008)\end{array}$ & $\begin{array}{l}-.028 * * \\
(.01)\end{array}$ & $\begin{array}{l}-.076^{* *} \\
(.023)\end{array}$ \\
\hline Multinationality & $\begin{array}{l}-.026 \\
(.022)\end{array}$ & $\begin{array}{l}-.006 \\
(.024)\end{array}$ & $\begin{array}{l}-.007 \\
(.057)\end{array}$ \\
\hline Capital Intensity & $\begin{array}{c}.056 \\
(.062)\end{array}$ & $\begin{array}{l}-.061 \\
(.07)\end{array}$ & $\begin{array}{l}-.06 \\
(.244)\end{array}$ \\
\hline R\&D Intensity & $\begin{array}{l}.614^{* * * *} \\
(.092)\end{array}$ & $\begin{array}{c}.098 \\
(.103)\end{array}$ & $\begin{array}{c}.107 \\
(.166)\end{array}$ \\
\hline Age & $\begin{array}{l}.003^{* * *} \\
(.001)\end{array}$ & $\begin{array}{l}.002 * * \\
(.001)\end{array}$ & $\begin{array}{l}.006^{* *} \\
(.002)\end{array}$ \\
\hline Company Tenure & $\begin{array}{l}.001^{*} \\
(.000)\end{array}$ & $\begin{array}{c}.001^{*} \\
(.001)\end{array}$ & $\begin{array}{c}.001 \\
(.001)\end{array}$ \\
\hline Position Tenure & $\begin{array}{l}-.003 * * * \\
(.001)\end{array}$ & $\begin{array}{l}-.003 * * * \\
(.001)\end{array}$ & $\begin{array}{l}-.006^{* * *} \\
(.001)\end{array}$ \\
\hline Education & $\begin{array}{c}.000 \\
(.002)\end{array}$ & $\begin{array}{l}-.002 \\
(.002)\end{array}$ & $\begin{array}{l}-.001 \\
(.006)\end{array}$ \\
\hline Functional Orientation & $\begin{array}{c}.002 \\
(.008)\end{array}$ & $\begin{array}{c}.018^{*} \\
(.009)\end{array}$ & $\begin{array}{l}-.001 \\
(.02)\end{array}$ \\
\hline $\mathbf{R}^{2}$ & .353 & .154 & .137 \\
\hline $\mathrm{F}$ & $11.757^{* * *}$ & $3.94 * * *$ & $3.43 * * *$ \\
\hline
\end{tabular}

Standard errors appear in parentheses

${ }^{*} \mathrm{p}<.05 ; \quad{ }^{* *} \mathrm{p}<.01 ; \quad{ }^{* * *} \mathrm{p}<.001 ; \quad \mathrm{N}=300$

Hypothesis 2 stated: The relationship between organizational and leadership factors and MNC performance will vary with the constraints on managerial discretion. Organizational and leadership factors have a greater impact on performance in high discretion settings in comparison to low discretion settings. To test, the firms were separated by industry and the tests were repeated. Dramatic differences in the proportion of variance explained were observed. There was a significant increase in the variance explained in the high discretion environment $[63.8 \%$ (ROS), $27.1 \%$ (ROI) and $31.5 \%$ (ROE)] and a decrease in the variance explained in the low discretion environment $[11.7 \%$ ROS; $11.7 \%$. (ROI) and $11.7 \%$ (ROE)]. Thus the hypothesis was supported by the observation of the differential impact of organization and leadership factors across different levels of managerial discretion. 
Table 4

Results of Pooled OLS Regression Analyses By Industry Environment ${ }^{a}$

\begin{tabular}{lcccccc}
\hline & \multicolumn{2}{c}{ ROS } & \multicolumn{2}{c}{ ROI } & \multicolumn{2}{c}{ ROE } \\
\cline { 2 - 7 } Variables & High & Low & High & Low & High & Low \\
Intercept & Discretion & Discretion & Discretion & Discretion & Discretion & Discretion \\
Multinationality & -.152 & -.065 & -.002 & -.082 & -.224 & -.226 \\
& $(.095)$ & $(.074)$ & $(.107)$ & $(.085)$ & $(.209)$ & $(.209)$ \\
Capital Intensity & $.091 \#$ & -.032 & -.031 & -.023 & $-.193 \#$ & -.009 \\
& $(.054)$ & $(.027)$ & $(.061)$ & $(.031)$ & $(.119)$ & $(.076)$ \\
R\&D Intensity & $.604 * * *$ & $.697 *$ & -.109 & .541 & -.047 & $2.105 *$ \\
& $(.129)$ & $(.333)$ & $(.145)$ & $(.380)$ & $(.284)$ & $(.936)$ \\
Age .003\# & $.003 \#$ & .002 & $.003 \#$ & $.007 *$ & $.013 * *$ & \\
& $(.002)$ & $(.001)$ & $(.002)$ & $(.002)$ & $(.003)$ & $(.004)$ \\
Company Tenure & .001 & .000 & .000 & .000 & .000 & .000 \\
& $(.001)$ & $(.000)$ & $(.000)$ & $(.000)$ & $(.002)$ & $(.002)$ \\
Position Tenure & $-.004 * * *$ & $-.002 *$ & $-.003 *$ & $-.003 *$ & $-.006 * *$ & $-.009 * *$ \\
& $(.001)$ & $(.000)$ & $(.000)$ & $(.001)$ & $(.002)$ & $(.003)$ \\
Education & .002 & -.004 & -.002 & -.004 & .002 & $-.023 \#$ \\
& $(.003)$ & $(.004)$ & $(.003)$ & $(.005)$ & $(.006)$ & $(.012)$ \\
Functional & -.006 & .006 & -.004 & .018 & .002 & .062 \\
Orientation & $(.015)$ & $(.014)$ & $(.017)$ & $(.016)$ & $(.033)$ & $(.040)$ \\
R ${ }^{2}$ & .638 & .117 & .271 & .117 & .315 & .117 \\
F & $11.585^{* * *}$ & $1.832 \#$ & $2.446 *$ & $1.857 \#$ & $\left.3.013^{*}\right)$ & $1.849 \#$ \\
\hline
\end{tabular}

aStandard errors appear in parentheses

High discretion environment: $N=140$

Low discretion environment: $N=160$

\#p $<.10 ; \quad{ }^{*} \mathrm{p}<.05 ; \quad{ }^{* *} \mathrm{p}<.01 ; \quad{ }^{* * *} \mathrm{p}<.001$

A consideration of the directional relationships between the individual organizational and managerial variables and firm performance in the overall sample as compared to the sample separated by level of discretion reveals an interesting picture as well. In the overall sample, there was no relationship between multinationality and performance. When industry is taken into account, multinationality was significantly and negatively related to two of the three performance indicators in the high discretion environment but no relationship was statistically discernible in the low discretion environment. This is perhaps a result of the high start up costs that firms in the U.S. electronics and computer industries face as they attempt to diversify geographically. 
Capital intensity did not seem to have any impact either in the overall sample or when the firms were separated by industry. On the other hand R\&D intensity was important to ROS in the overall sample as well as in both discretionary environments. This finding may imply that investment in developing new products and technologies is one of the few variables that consistently enhances performance even in low discretion settings.

Among the managerial variables, the consistency across the discretionary environments was interesting and surprising. CEO age seemed to have a positive impact on performance, in the overall sample and in the high and low discretion environments as well. This suggests that older CEOs were able to improve performance to a greater extent than their younger counterparts, regardless of the industry in which they operated in. Position tenure, on the other hand, was negatively related to every performance indicator in both settings. This seems to imply that the CEO might be getting 'stale in the saddle,' reinforcing Miller's (1991) contention that long tenured CEOs may rely on their past accomplishments and resist reorienting their organizations to changes in the environment, thus negatively impacting performance.

Overall, the results of this study tell an interesting story that sheds new light on research investigating the determinants of MNC performance. They suggest that the ambiguity and contradictions that characterize prior findings must be interpreted with caution. Instead of dismissing and accepting the results of individual studies based on theoretical or methodological merits alone, researchers must attempt to search for underlying explanations which may explain why a factor such as multinationality may be positively related to performance in some settings, and negatively related or not related at all to performance in others.

We suggest that managerial discretion, conceptualized in this study as industry membership, offers one avenue worthy of pursuit. Under the theoretical umbrella that is discretion, it is possible to argue that the relative strength of the impact of environmental, organizational and leadership factors on firm performance will vary. While it is entirely possible, as this study has indicated, that $R \& D$ intensity or CEO age may have a universal impact while others such as multinationality may have a contingency impact, the extent of the impact could depend on the latitude of action available to top managers or the deterministic nature of the environment.

\section{Limitations}

The results of this study are exploratory and must be interpreted with caution. The small sample size and the restriction to two settings limit the generalizability of findings. Future efforts must replicate the test in larger and more diverse sample. Further investigations can also refine the methodology by using generalized least squares procedures that specifically control for autocorrelation. 


\section{Conclusion}

This study has attempted to integrate the fragmented findings that characterize research about the determinants of performance in multinational organizations. By considering the research stream through the lens of strategic management, it was suggested that MNC performance is essentially a result of environmental, organizational and leadership factors. In so doing, it responds to Dunning's (1989) call for more interdisciplinary research and heeds the advice of Bartlett and Ghoshal (1991) and Buckley (1993) who advocate that international business researchers draw on the strategic management literature to explore the role of managers in international, strategic and organizational contexts. Further, it was suggested that the contradictions of prior findings can be reconciled under the theory of managerial discretion which suggests that the relative importance of the environment and strategic managers (and therefore organizational factors) can vary across situations. Thus it is possible that some factors may have a significant positive or negative impact on performance in some situations and a minimal or no impact on performance in others.

This study has some very important implications for researchers studying MNCs. It suggests that an investigation of the determinants of MNC performance should be preceded by an evaluation of the factors that enhance and constrain managerial discretion. Such an evaluation will provide insight to the relative importance of environmental, organization and leadership factors. It also suggests that single industry studies or studies of firms facing relatively similar constraints are necessary to accurately identify the factors that actually influence MNC performance. Since discretion can vary widely by the setting, results of studies which include samples of firms from multiple industries may be contaminated by variations in managerial latitude.

Practitioners who study MNCs should also be cognizant of the latitude of action available to top executives before arriving at prescriptions about avenues to survival and success. Although managers are important, their ability to impact performance can vary by the constraints on their discretion. Thus in low discretion settings such as petroleum refining, efforts to improve performance through executive succession and recruitment may not always evoke the desired results. Similarly, the impact of changed strategies and new resource allocation decisions may be slower in some industries than others. Thus the criteria for measuring the success of managers and strategies should reflect the relative freedom available to top managers. 


\section{References}

Aldrich, H.E. Organizations and Environments. Englewood Cliffs, N.J: Prentice-Hall, 1979.

Bartlett, C.A. and S. Ghoshal. "Global Strategic Management: Impact on the New Frontiers of Strategy Research.” Strategic Management Journal 12 (1991): 5-16.

Blaine, M. "Comparing the Profitability of Firms in Germany, Japan, and the United States." Management International Review 34(2) (1994): 125-148.

Buckley. P.J. "The Role of Management in Internalisation Theory." Management International Review 33(3) (1993): 197-207.

Buckley, P.J., J.H. Dunning, and R.D. Pearce. "The Influence of Firm Size, Industry, Nationality and Degree of Multinationality on the Growth and Profitability of the World's Largest Firms 1962-1972." Weltwirtschaftlisches Archiv 2 (1978): 243-257.

Carlsson, G., and K. Karlsson. "Succession and Performance Among School Superintendents." American Sociological Review 35 (1970): 710-718.

Carpano, C., J.J. Chrisman, and K. Roth. "International Strategy and Environment: An Assessment of the Performance Relationship." Journal of International Business Studies 25 (1994): 639-656.

Chaganti, R and R. Sambharya. "Strategic Orientation and Characteristics of Upper Management." Strategic Management Joumal 8 (1987): 393-401.

Child, J.. "Organization Structure, Environment and Performance: The Role of Strategic Choice." Sociology 6 (1972): 2-21.

Cyert, R.M. and J.G. March. A Behavioral Theory of the Firm. Englewood Cliffs, NJ: Prentice-Hall, 1963.

Daniels, J.D. and J. Bracker. "Profit Performance: Do Foreign Operations Make a Difference?" Management International Review 29 (1989): 46-56.

Dearborn, D.C. and H.A. Simon. "Selective Perceptions: A Note on the Departmental Identifications of Executives." Sociometry 21 (1958): 140-144.

Dunning, J.H. International Production and the Multinational Enterprise. London: George Allen \& Unwin, 1981.

Dunning, J.H. "The Study of International Business: A Plea for a More Interdisciplinary Approach.” Journal of International Business Studies 20 (1989): 411-436. 
Finkelstein, S., and D.C. Hambrick. "Top Management Team Tenure and Organizational Outcomes: The Moderating Role of Managerial Discretion." Administrative Science Quarterly 35 (1990): 484-503.

Geringer, J.M., P.W. Beamish, and R.C. daCosta. "Diversification Strategy and Internationalization: Implications for MNE Performance." Strategic Management Journal 10 (1989): 109-119.

Grant, R.M. "Multinationality and Performance Among British Manufacturing Companies." Journal of International Business Studies 18 (1987): 79-89.

Grant, R.M., A.P. Jammine, and H. Thomas. "Diversity, Diversification, and Profitability Among British Manufacturing Companies, 1972-84." Academy of Management Journal 31 (1988): 771-801.

Gupta, A.K. and V. Govindarajan. "Business Unit Strategy, Managerial Characteristics and Business Unit Effectiveness at Strategy Implementation." Academy of Management Journal 27 (1984): 25-41.

Haar, J. "A comparative analysis of the profitability performance of the largest U.S., European, and Japanese multinational enterprises." Management International Review 29(3) (1989): 5-18.

Hambrick, D.C. and S. Finkelstein. "Managerial Discretion: A Bridge Between Polar Views of Organizational Outcomes." In L.L. Cummings and Barry M. Staw (eds.), Research in Organizational Behavior 9 (1987): 369-406. Greenwich, CT: JAI Press.

Hambrick, D.C., and P.A. Mason, "Upper Echelons: The Organization as a Reflection of its Top Managers." Academy of Management Review 9 (1984): 193-206.

Hannan, M.T. and J.H. Freeman "The Population Ecology of Organizations." American Journal of Sociology 82 (1977): 929-964.

Kim, W.C., P. Hwang, and W.P. Burgers. "Global Diversification Strategy and Corporate Profit Performance." Strategic Management Journal 10 (1989): 45-57.

Kimberly, J.R., and M.J. Evanisko. "Organizational Innovation: The Influence of Individual, Organizational and Contextual Factors on Hospital Adoptions of Technological and Administrative Innovations." Academy of Management Journal 24 (1981): 689-713.

Kirchner, W.K. “Age Differences in Short Term Retention of Rapidly Changing Information." Journal of Experimental Psychology 55 (1958): 352-358.

Kotter, J.P. The General Managers. New York, NY: The Free Press, 1982.

Kumar, M.S. Growth, Acquisition and Investment. Cambridge, U.K.: Cambridge University Press, 1984. 
Levine, S., and P.E. White. "Exchange as a Conceptual Framework for the Study of Interorganizational Relationships." Administrative Science Quarterly 5 (1961): 583-601.

Lieberson, S., and J.F. O'Connor. "Leadership and Organizational Performance: A study of Large Corporations." American Sociological Review 37 (1972): 117-130.

Lorange, P. Corporate Planning, Prentice Hall, Englewood Cliffs: NJ, 1980.

March, J.G., and H.A. Simon. Organizations. New York: John Wiley, 1958.

Michel, A., and I. Shaked. "Multinational Corporations vs. Domestic Corporations: Financial Performance and Characteristics." Journal of International Business Studies 16 (1986): 89-100.

Miles, R.E., and C.C. Snow. Organizational Strategy. Structure, and Process. New York: McGraw-Hill, 1978.

Miller, D. "Stale in the Saddle: CEO Tenure and the Match Between Organization and the Environment." Management Science 37 (1991): 34-52.

Mitchell, W., J.M. Shaver, and B. Yeung. "Performance Following Changes of International Presence in Domestic and Transition Industries." \ournal of International Business Studies 24 (1993): 647-669.

Pearce, J.A., and R.B. Robinson. "A Measure of Social Power in Strategic Decision Making." Strategic Management Journal 8 (1987): 297-304.

Porter, M.E. Competitive Advantage of Nations. New York, NY: Free Press, 1990.

Ramaswamy, K. "Multinationality and Performance: A Synthesis and Redirection." Advances in Intemational Comparative Management 7 (1992): 241-267.

Rugman, A.M. "The Comparative Performance of U.S. and European Multinational Enterprises, 1970-79." Management International Review 23(2) (1983): 4-14.

Severn, A.K., and M.M. Laurence. "Direct Investment, Research Intensity, and Profitability." Journal of Financial and Quantitative Economics 29 (1974): 181-190.

Siddharthan, N.S. and S. Lall. "The Recent Growth of the Largest U.S. Multinationals." Oxford Bulletin of Economics and Statistics 44 (1982): 1-12.

Stevens, J.M., J.M. Beyer, and H.M. Trice. "Assessing Personal Role and Organizational Predictors of Managerial Commitment." Academy of Management Journal 18 (1978): 74-81.

Sullivan, D.. "Measuring the Degree of Internationalization of a Firm." Journal of International Business Studies 25 (1994a): 325-342. 
Sullivan, D. "The "Threshold of Internationalization:" Replication, Extension, and Reinterpretation." Management International Review 34(2) (1994b): 165-186.

Thomas, A.S., R.J. Litschert, and K. Ramaswamy. "The Performance Impact of Strategy Manager Coalignment: An Empirical Examination.” Strategic Management Journal 12 (1991): 509-522.

Tushman, M.L., and E. Romanelli. "Organizational Evolution: A Metamorphosis of Convergence and Reorientation." In L.L. Cummings and Barry M. Staw (eds.), Research in Organizational Behavior 7 (1985): 171-222. Greenwich, CT: JAI Press.

Vernon, R. Sovereignty at Bay: The Multinational Spread of U.S. Enterprises. New York: Basic Books, 1971.

Wiersema, M.F. and K.A. Bantel. "Top Management Team Demography and Corporate Strategic Change. " Academy of Management Journal 35 (1992): 91-121. 